\section{Arsenate Adsorption on an Fe-Ce Bimetal Oxide Adsorbent: Role of Surface Properties}

YU ZHANG, MIN YANG, * XIAO-MIN DOU, HONG HE, AND DONG-SHENG WANG State Key Laboratory of Environmental Aquatic Chemistry, Research Center for Eco-Environmental Sciences, Chinese Academy of Sciences, Post Office Box 2871, Beijing 100085, China

$\mathrm{An} \mathrm{Fe}-\mathrm{Ce}$ bimetal adsorbent was investigated with X-ray powder diffraction (XRD), transmission electron micrograph (TEM), Fourier transform infrared spectra (FTIR), and X-ray photoelectron spectroscopy (XPS) methods for a better understanding of the effect of surface properties on arsenate $(\mathrm{As}(\mathrm{V}))$ adsorption. In the adsorption test, the bimetal oxide adsorbent showed a significantly higher As(V) adsorption capacity than the referenced $\mathrm{Ce}$ and $\mathrm{Fe}$ oxides $\left(\mathrm{CeO}_{2}\right.$ and $\left.\mathrm{Fe}_{3} \mathrm{O}_{4}\right)$ prepared by the same procedure and some other arsenate adsorbents reported recently. XRD measurement of the adsorbent demonstrated that the phase of magnetite $\left(\mathrm{Fe}_{3} \mathrm{O}_{4}\right)$ disappears gradually with the increasing dosage of $\mathrm{Ce}^{4+}$ ions until reaching a molar ratio of $\mathrm{Ce}^{4+}$ to $\mathrm{Fe}^{3+}$ and $\mathrm{Fe}^{2+}$ of 0.08:0.2:0.1 (Fe-Ce08 refers to the adsorbent prepared at this ratio), and the phase of $\mathrm{CeO}_{2}$ begins to appear following a further increase of the Ce dose. Combined with the results of TEM observation, it was assumed that a solid solution of $\mathrm{Fe}-\mathrm{Ce}$ is formed following the disappearance of the magnetite phase. Occurrence of a characteristic surface hydroxyl group (M$\mathrm{OH}$, metal surface hydroxyl, $1126 \mathrm{~cm}^{-1}$ ), which showed the highest band intensity in the solid solution state, was confirmed on the bimetal oxide adsorbent by FTIR. Quantificational calculation from the XPS narrow scan results of $0(1 \mathrm{~s})$ spectra also indicated that the formation of the bimetal $\mathrm{Fe}-\mathrm{Ce} 08$ was composed of more hydroxyl $(30.8 \%)$ than was the formation of $\mathrm{CeO}_{2}$ and $\mathrm{Fe}_{3} \mathrm{O}_{4}(12.6 \%$ and $19.6 \%)$. The results of adsorption tests on $\mathrm{Fe}-\mathrm{Ce} 08$ at different $A s(V)$ concentrations indicated that both the integral area of the As- 0 band at $836 \mathrm{~cm}^{-1}$ and the As(V) adsorption capacity increased almost linearly with the decrease of the integral area of $\mathrm{M}-\mathrm{OH}$ bands at $1126 \mathrm{~cm}^{-1}$, proving that the adsorption of $\mathrm{As}(\mathrm{V})$ by $\mathrm{Fe}-\mathrm{Ce} 08$ is mainly realized through the mechanism of quantitative ligand exchange. The atomic ratio of $\mathrm{Fe}$ on $\mathrm{Fe}-\mathrm{Ce} 08$ decreased from $20.1 \%$ to $7.7 \%$ with the increase of the As atom ratio from 0 to $16 \%$ after $A s(\mathrm{~V})$ adsorption, suggesting that $\mathrm{As}(\mathrm{V})$ adsorption might be realized through the replacement of the $\mathrm{M}-\mathrm{OH}$ group of $\mathrm{Fe}(\mathrm{Fe}-\mathrm{OH})$ with arsenate. The well splitting of three $v_{3}$ bands at As -0 band $\left(836 \mathrm{~cm}^{-1}\right)$ of FTIR and the hydroxyl ratio (1.7) of $\mathrm{Fe}-\mathrm{Ce} 08$ calculated from the XPS results suggested that the diprotonated monodentate complex $\left(\mathrm{SOAs} O(\mathrm{OH})_{2}\right)$ is possibly dominant on the surface of $\mathrm{Fe}-\mathrm{Ce} 08$.

* Corresponding author phone: +86 106292 3475; fax: +86 10 6292 3541; e-mail: yangmin@mail.rcees.ac.cn.

7246 - ENVIRONMENTAL SCIENCE \& TECHNOLOGY / VOL. 39, NO. 18, 2005

\section{Introduction}

Removal of $\mathrm{As}(\mathrm{V})$ from groundwater by adsorption is one of the most effective As removal methods, with the advantage of having high removal efficiency without yielding harmful byproducts, and has been given wide attention recently ( 1 , 2). Some species of the iron oxides, as cheap adsorbents, have been reported to be effective for arsenic removal because of Fe's affinity toward inorganic arsenic species and its consequent selectivity of the adsorption process (3). In most cases, however, iron oxides present low arsenic adsorption capacities, slow adsorption processes, and narrow optimum $\mathrm{pH}$ ranges $(4,5)$, which compromises their applicability.

On the other hand, hydrous oxides of rare earth elements have been proposed as a new sorption medium for removing aqueous hazardous anions such as arsenate, fluoride, and phosphate. They have attracted attention because of their relatively high adsorption capacities $(6,7)$. The relatively small ionic potential and strong basicity of rare earth ions results in a strong tendency to dissociate $\mathrm{OH}$ groups into hydroxyl ions (6). One of the problems for the use of rare earth compounds is the high cost. Recently, many researchers have tried to develop new arsenate adsorbents with a high adsorption capacity and relatively low cost (8). However, development of new adsorbents still relies on experience because of a lack of a thorough understanding of adsorption mechanisms. Elucidation of the effect of surface properties on the adsorption behavior of arsenic will greatly promote the understanding of adsorption mechanisms.

Extensive theoretical and experimental work on anion adsorption on metal oxides has been carried out in the past 40 years (9), focusing primarily on elucidating reactions between adsorbents and adsorbates. Recent developments in analytical techniques have started to provide detailed structural and chemical observation of adsorbates (10) and to provide more direct and quantitative information of adsorbed complexes, such as the summary by Brown (11) in his spectroscopic studies of the chemisorption reaction mechanism at the oxide-water interface. Various analytical methods, including spectroscopy, diffractometry, thermal analysis, and microscopy, are now available for the identification and characterization of metal oxide adsorbents. Among the many spectroscopic methods, extended X-ray absorption fine structure spectroscopy (EXAFS), which provides definitive information on inner-versus outer-sphere bonding, has received wide attention (12). However, other methods such as FTIR and XPS may be equally as promising. Sun and Doner (13) examined the $\mathrm{M}-\mathrm{OH}$ stretching modes of deuterated goethite in the presence of As $(\mathrm{V})$ using FTIR. On the basis of transmission and attenuated total reflection (ATR) modes in dry systems, three bands of OD stretching, corresponding to singly, doubly, and triply coordinated $\mathrm{OH}$ hydroxyls on the goethite surface, were shown. Sun and Doner concluded that arsenate oxyanions mostly replace with singly coordinated surface hydroxyl groups by forming bidentate binuclear complexes $\mathrm{Fe}-\mathrm{O}-\mathrm{AsO}(\mathrm{OH})-\mathrm{O}-\mathrm{Fe}$. Goldberg and Johnston (14) studied arsenic adsorption at different pHs on amorphous $\mathrm{Al}$ and Fe oxides using FTIR spectroscopy, Raman spectroscopy, and surface complexation modeling, proving that the main mechanism of $A s(V)$ sorption by the amorphous Fe oxide was due to the formation of inner-sphere arsenate complexes on the surfaces. The splitting of As- O, B-O, P-O, and $\mathrm{S}-\mathrm{O}$ degenerate vibrational modes have been used for interpretation of FTIR spectra under different adsorption environments on the basis of group theory (15-18). The dominant species of surface complexes has been successfully speculated. 


\section{TABLE 1. Physical-Chemical Property of Different Adsorbents}

$\begin{array}{lllcc}\text { molar concentration of Ce on Fe oxide }\left(\mathbf{m o l ~ L}^{-1}\right) & \mathbf{0} & \mathbf{0 . 0 1} & \mathbf{0 . 0 5} & \mathbf{0 . 0 8} \\ \text { name of adsorbents } & \text { Fe oxide } & \text { Fe-Ce01 } & \text { Fe-Ce05 } & \text { Fe-Ce08 } \\ \text { pHzpc } & 6.2 & & 5.8 \\ \text { specific surface area }\left(\mathrm{m}^{2} \mathrm{~g}^{-1}\right) & 98 & & 90\end{array}$

On the other hand, XPS, as an important technique for surface analysis, can provide chemical state information about altered and unaltered surfaces. Ding (19) carried out XPS measurements on a pristine $\mathrm{FeOOH}$ substrate and its surface complexes with $\mathrm{AsO}_{4}{ }^{3-}, \mathrm{PO}_{4}{ }^{3-}, \mathrm{CrO}_{4}{ }^{2-}, \mathrm{Zn}^{2+}$, and $\mathrm{Pb}^{2+}$. By tracking $\mathrm{O}(1 \mathrm{~s})$ and Fe core level (e.g., $\mathrm{Fe}(2 \mathrm{p}), \mathrm{Fe}(3 \mathrm{p})$, and $\mathrm{Fe}(3 \mathrm{~s})$ ) binding energy (BE) shifts relative to those of $\mathrm{FeOOH}$ itself, an assessment could be made of the magnitude and direction of electron transfer between substrate and adduct. Their findings indicate that substantial and variable charge transfer occurs in which the $\mathrm{FeOOH}$ substrate can function either as a Lewis acid or a base in its interaction with different adsorbates. In addition, multiplet peaks of narrow scans of $\mathrm{O}(1 \mathrm{~s})$ regions can provide significant information about the amount of oxide lattice oxygen $\left(\mathrm{O}^{2-}\right)$, hydroxyl bonded to metal $\left(\mathrm{OH}^{-}\right)$, and adsorbed water $\left(\mathrm{H}_{2} \mathrm{O}\right)$ on the surface of oxides (20).

As discussed above, recent research on $\mathrm{As}(\mathrm{V})$ adsorption has made significant progress. However, most of the previous studies have focused on interactions between As $(\mathrm{V})$ and the surfaces of natural oxide systems, primarily Fe or Al minerals. Little is known about the relationship between the surface property and $\mathrm{As}(\mathrm{V})$ adsorption performance of synthetic adsorbents, which is vital for the development of new arsenate adsorbents.

In our recent research, metal $(\mathrm{Ce}, \mathrm{La}$, and $\mathrm{Zr}$ ) doped $\mathrm{Fe}$ oxide materials were used for the removal of anions from groundwater. Of several bimetal materials, $\mathrm{Fe}-\mathrm{Ce}$ material showed the highest sorption capacity and a wide $\mathrm{pH}$ range of 3-7 for As(V) removal. The maximum adsorption capacity of the $\mathrm{Fe}-\mathrm{Ce}$ material for $\mathrm{As}(\mathrm{V})$ ions was significantly higher than those of other adsorbents reported, and the preparation and $\mathrm{As}(\mathrm{V})$ adsorption properties of the Fe-Ce system have been documented $(21,22)$. The objectives of this paper are to characterize the surface properties of the $\mathrm{Fe}-\mathrm{Ce}$ system by comparing them with the referenced and typical materials and to determine the surface structure and chemical functional groups responsible for the adsorption of As(V) using XRD, TEM, FTIR, XPS spectra, and other techniques. On the basis of these results, we propose a possible mechanism for the adsorption of $\mathrm{As}(\mathrm{V})$ on the surface of bimetal adsorbents and make some suggestions for the development of new adsorbents.

\section{Materials and Methods}

Materials. All the chemicals used were of analytical reagent grade. A $1000 \mathrm{mg} \mathrm{L}^{-1} \mathrm{As}(\mathrm{V})$ stock solution was prepared by dissolving $4.1653 \mathrm{~g} \mathrm{Na}_{2} \mathrm{HAsO}_{4} \cdot 7 \mathrm{H}_{2} \mathrm{O}$ in $1 \mathrm{~L}$ of distilled water. As $(\mathrm{V})$-bearing water was prepared by diluting $\mathrm{As}(\mathrm{V})$ stock solution to given concentrations with distilled water. Fe-Ce bimetal oxide adsorbents were prepared by the coprecipitation method (22). 0.01, 0.05, 0.08, or $0.11 \mathrm{~mol} \mathrm{~L}^{-1} \mathrm{Ce}\left(\mathrm{SO}_{4}\right)_{2}$. $4 \mathrm{H}_{2} \mathrm{O}$ was dissolved in $2 \mathrm{~L}$ of distilled water together with 0.2 mol L${ }^{-1} \mathrm{FeCl}_{3} \cdot 6 \mathrm{H}_{2} \mathrm{O}$ and $0.1 \mathrm{~mol} \mathrm{~L}^{-1} \mathrm{FeCl}_{2} \cdot 4 \mathrm{H}_{2} \mathrm{O}$. Under gentle stirring, the $\mathrm{pH}$ was slowly raised to a $\mathrm{pH}$ of around 10 by the addition of $6 \mathrm{~mol} \mathrm{~L}^{-1} \mathrm{NaOH}$ solution. Stirring was continued for $30 \mathrm{~min}$. After $10 \mathrm{~h}$ of aging at room temperature, the suspension was repeatedly washed with distilled water and then was dried at $100{ }^{\circ} \mathrm{C}$ for $10 \mathrm{~h}$. The dry material was crushed and stored in a desiccator.

Hydrous cerium oxide and iron oxide were prepared as the referenced metal oxides by referring to the above coprecipitation method $(6,22)$. The types of different adsorbents were characterized as shown in Table 1.

Adsorption Experiment. A given volume of $\mathrm{As}(\mathrm{V})$ stock solution was added separately to a conical flask, and the volume was increased to $100 \mathrm{~mL}$ with distilled water. After $\mathrm{pH}$ adjustment, the flasks were shaken at $120 \mathrm{rpm}$ and $20^{\circ} \mathrm{C}$ for approximately $24 \mathrm{~h}$ following the addition of the adsorbent. Then, the solution was filtered with a $0.45-\mu \mathrm{m}$ membrane filter for analysis. The $\mathrm{pH}$ was measured with a pH meter (model 828, Orion, U.S.). As(V) was analyzed on an atomic fluorescence spectrometer (HG-AFS-610, Beijing Raileigh Analytic Instrument Corporation, China). The adsorption isotherms were studied by varying doses of adsorbent under a fixed $\mathrm{As}(\mathrm{V})$ concentration $\left(13.3 \mathrm{mmol} \mathrm{L}^{-1}\right)$. Isotherms were modeled using the Langmuir equation. Container adsorption tests were also carried out to find blank adsorption. Experiments were repeated three times, and all of the data are the average of the three.

Adsorbent Characterization. An X-ray powder diffractometer (Rigaku III/B max) was used to analyze the adsorbents' crystalline structures. The radiation source was $\mathrm{Cu}$ $\mathrm{K} \alpha$. The applied current was $30 \mathrm{~mA}$, and the voltage was 40 $\mathrm{kV}$. During the analysis, the sample was scanned from 20 to $80^{\circ}$ at a speed of $0.4^{\circ} / \mathrm{min}$.

Transmission electron micrograph (TEM) images were recorded on a H800 transmission electron micrograph (Hitachi, Japan) operating at $200 \mathrm{kV}$. Samples for TEM were gently ground and dispersed in ethanol and then were dropcast onto 200 -mesh copper grids coated with a holey carbon film.

FTIR spectra of $\mathrm{Fe}-\mathrm{Ce}$ adsorbents before and after adsorption were recorded on a Perkins Elmer (U.S.) system 2000 spectrophotometer with a resolution of $2 \mathrm{~cm}^{-1}$. Samples for FTIR determination were ground with special grade $\mathrm{KBr}$ in an agate mortar. To ensure quantitative $\mathrm{M}-\mathrm{OH}$ analyses, we ground the sample with $\mathrm{KBr}$ in a fixed ratio (3\%). The same amount of mixed powder was also used to prepare the pellet for FTIR. All IR measurements were carried out at room temperature. Splitting of $v_{3}$ vibration was performed by referring to Arai and sparks (17). Both the second derivative and deconvoluted spectra were used to determine the number of overlapping bands. Then, Gaussian profile fitting was performed to reveal the assemblage of multiple $v_{3}$ bands using the Jandel PeakFit software (PeakFit-Jandel Scientific Software, San Rafael, CA).

The binding energies and atomic ratio were measured on an XPS equipped with an ESCA-Lab- 5 spectrometer. The pass energy was $50 \mathrm{eV}$ and conventional $\mathrm{Al} \mathrm{K} \alpha$ anode radiation source was used as the excitation source. The XPS results were corrected by C 1 s and the calibration energy was $284.6 \mathrm{ev}$. XPS data process and peak fitting was performed using a nonlinear least-squares fitting program (XPSPeak software 4.1, Raymund W. M. Kwok,). The fitted peak parameters are provided in Table 2 on the basis of reference 20 and analytical conditions.

The specific surface areas of the $\mathrm{Fe}-\mathrm{Ce} 0.08$, hydrous cerium oxide, and iron oxide adsorbents were determined by the BET method with $\mathrm{N}_{2}$ gas (ASAP2000V3.01A; Micromeritics, Norcross, GA).

The points of zero charge (pHzpc) of the $\mathrm{Fe}-\mathrm{Ce}$, Ce oxide, and $\mathrm{Fe}$ oxide adsorbents were determined by the titration method (23). This method consists of obtaining curves of 


\begin{tabular}{|c|c|c|c|c|}
\hline sample & peak $^{a}$ & B. E. (ev) & fwhm $(e V)^{b}$ & percent $(\%)^{c}$ \\
\hline \multirow[t]{3}{*}{ Fe oxide } & $\mathrm{O}^{2-}$ & 529.69 & 1.7 & 72.08 \\
\hline & $\mathrm{OH}^{-}$ & 530.06 & 1.7 & 12.62 \\
\hline & $\mathrm{H}_{2} \mathrm{O}$ & 531.69 & 2 & 15.30 \\
\hline \multirow[t]{3}{*}{ Ce oxide } & $\mathrm{O}^{2-}$ & 529.45 & 1.7 & 42.09 \\
\hline & $\mathrm{OH}^{-}$ & 530.81 & 1.7 & 19.59 \\
\hline & $\mathrm{H}_{2} \mathrm{O}$ & 531.68 & 2 & 38.32 \\
\hline \multirow[t]{3}{*}{$\mathrm{Fe}-\mathrm{Ce} 08$} & $\mathrm{O}^{2}-$ & 529.44 & 1.7 & 18.37 \\
\hline & $\mathrm{OH}^{-}$ & 529.74 & 1.7 & 33.79 \\
\hline & $\mathrm{H}_{2} \mathrm{O}$ & 531.27 & 2 & 49.83 \\
\hline \multirow[t]{3}{*}{$\mathrm{Fe}-\mathrm{Ce} 08-\mathrm{As}$} & $\mathrm{O}^{2-}$ & 529.66 & 1.7 & 25.72 \\
\hline & $\mathrm{OH}^{-}$ & 530.55 & 1.7 & 56.06 \\
\hline & $\mathrm{H}_{2} \mathrm{O}$ & 531.81 & 2 & 18.22 \\
\hline
\end{tabular}

a Surface species: $\mathrm{O}^{2-}$ : oxygen bonded to metal; $\mathrm{OH}^{-}$: hydroxyl bonded to metal; $\mathrm{H}_{2} \mathrm{O}$ : sorbed water. ${ }^{b}$ All peaks modeled as $50: 50$ Gaussian:Lorentzian. The full width at half-maximum (fwhm) values were not adjusted during fitting. ${ }^{c}$ The percentage represents the contribution of each peak to the total number of counts under the $\mathrm{O}(1 \mathrm{~s})$ peak.

surface charges as a function of $\mathrm{pH}$ at different ionic strengths of the supporting electrolyte $\left(\mathrm{NaClO}_{4}\right)$. The points of intersection of the above curves correspond to the pHzpcs. The experiments were carried out in triplicate, and the average data were used for each point.

\section{Results and Discussion}

Arsenate Adsorption Behavior. The Langmuir equation was applied for adsorption equilibrium as follows:

$$
C_{\mathrm{e}} / Q_{\mathrm{e}}=1 /\left(Q_{0} b\right)+\left(C_{\mathrm{e}} / Q_{0}\right)
$$

where $C_{\mathrm{e}}$ is the equilibrium concentration of $\mathrm{As}(\mathrm{V})(\mathrm{mmol}$ $\left.\mathrm{L}^{-1}\right), Q_{\mathrm{e}}$ is the amount adsorbed under equilibrium $(\mathrm{mmol}$ $\left.\mathrm{g}^{-1}\right), Q_{0}\left(\mathrm{mmol} \mathrm{g}^{-1}\right)$ is the theoretical maximum adsorption capacity, and $b\left(\mathrm{~L} \mathrm{mmol}^{-1}\right)$ is a Langmuir binding constant related to the energy of adsorption. Linear plots of $\mathrm{Ce} / Q_{\mathrm{e}}$ versus Ce for $\mathrm{Fe}-\mathrm{Ce} 08$ were obtained with corr. coefft $\left(R^{2}\right)$, $b$, and $Q_{0}$ of $0.99,18.59 \mathrm{~L} \mathrm{mmol}^{-1}$, and $2.00 \mathrm{mmol} \mathrm{g}^{-1}$, respectively, indicating that adsorption of $\mathrm{As}(\mathrm{V})$ onto $\mathrm{Fe}-\mathrm{Ce} 08$ obeys the Langmuir isotherm model at the given range of As(V) concentration. It is clear that the $Q_{0}\left(2.00 \mathrm{mmol} \mathrm{g}^{-1}\right)$ of $\mathrm{Fe}-$ Ce08 was significantly higher than those of the two referenced materials $\left(0.35 \mathrm{mmol} \mathrm{g}^{-1}\right.$ for the Fe oxide and $0.45 \mathrm{mmol} \mathrm{g}^{-1}$ for the Ce oxide), the iron hydroxides, and some other arsenate adsorbents reported recently $(24-30)$. In the next section, the differences in adsorption performance will be discussed in relation to the differences in structures between the $\mathrm{Fe}-\mathrm{Ce}$ adsorbent and its referenced oxide materials.

Surface Properties. XRD Spectra and TEM Images. Figure 1 shows the XRD patterns of Fe oxide, Ce oxide, and bimetal $\mathrm{Fe}-\mathrm{Ce}$ systems. According to the Joint Committee on Powder Diffraction System (JCPDS) file, the major phase of Fe oxide is magnetite $\left(\mathrm{Fe}_{3} \mathrm{O}_{4} ; 2 \theta: 35.56,62.80,30.14^{\circ} ; d\right.$ value: 2.5225, $1.4784,2.9626)$, which matches well with the expected patterns, and the XRD patterns of $\mathrm{CeO}_{2}$ exhibited a fluoritestructure diffraction pattern $(2 \theta: 28.38,47.04,56.16$; $d$ value: $3.1422,1.9302,1.6364)$. With the doping of $\mathrm{Ce}^{4+}$ into the $\mathrm{Fe}^{2+} /$ $\mathrm{Fe}^{3+}$ solution system, the principal peaks of $\mathrm{Fe}_{3} \mathrm{O}_{4}$ phase gradually disappeared, indicating the disrupting effects of $\mathrm{Ce}^{4+}$ on the formation of $\mathrm{Fe}_{3} \mathrm{O}_{4}$ crystals. The occurrence of amorphous structures of $\mathrm{Fe}-\mathrm{Ce} 05$ ( $\mathrm{Fe}-\mathrm{Ce}$ oxide with a molar ratio of $\mathrm{Ce}^{4+}$ to $\mathrm{Fe}^{3+}$ and $\mathrm{Fe}^{2+}$ as 0.05:0.2:0.1) and $\mathrm{Fe}-\mathrm{Ce} 08$ suggest the formation of a possible solid solution structure under the test conditions. No goethite peak appears in XRD spectra. However, as will be shown in the next section, goethite is clearly present in the FTIR spectra of Fe-Ce05. This phenomenon is perhaps due to the lack of sensitivity

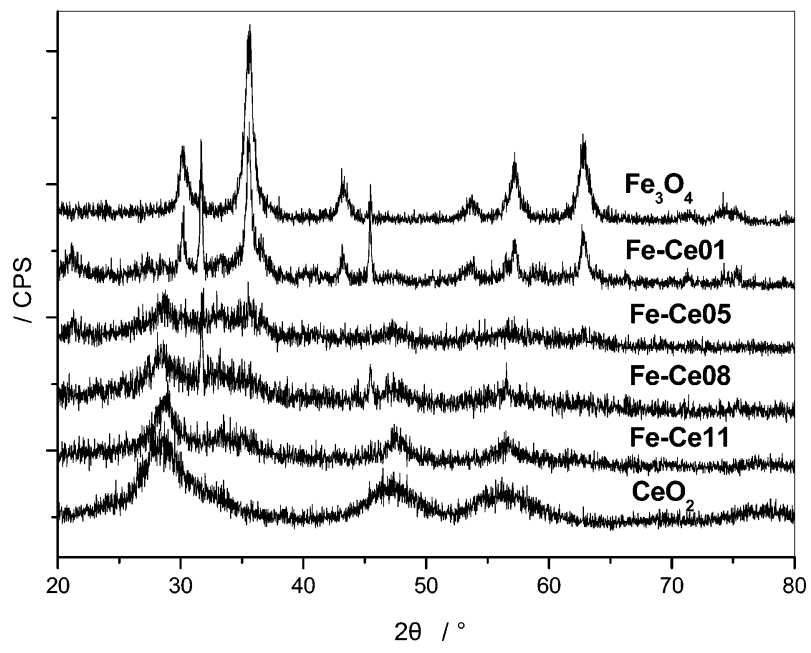

FIGURE 1. XRD patterns of $\mathrm{Fe}_{3} \mathrm{O}_{4}, \mathrm{CeO}_{2}$, and $\mathrm{Fe}-\mathrm{Ce}$ systems.

in XRD analyses (i.e., less than 5 wt \%). It is clear that FeCe08 has a structure that was completely different from those of its referenced materials $\left(\mathrm{Fe}_{3} \mathrm{O}_{4}\right.$ and $\left.\mathrm{CeO}_{2}\right)$, indicating that the $\mathrm{Fe}-\mathrm{Ce}$ system was not a simple mixture of the referenced Fe oxide and Ce oxide. With the further increase of $\mathrm{Ce}^{4+}$ dose ( $\mathrm{Fe}-\mathrm{Ce} 11)$, however, peaks representing $\mathrm{CeO}_{2}$ phase appeared, indicating the formation of a new phase with a microcrystalline structure.

The three oxides, $\mathrm{Fe}_{3} \mathrm{O}_{4}, \mathrm{Fe}-\mathrm{Ce} 08$, and $\mathrm{CeO}_{2}$, were examined by TEM, and the results are shown in Figure 2a, $\mathrm{b}$, and c, respectively. Aggregates of the crystal particles of $\mathrm{Fe}_{3} \mathrm{O}_{4}$ with an average diameter of $10-20 \mathrm{~nm}$ and clear edges can be clearly seen in Figure $2 \mathrm{a}$. Figure $2 \mathrm{~b}$ shows aggregates of larger amorphous particles $(20-30 \mathrm{~nm})$, which were considered to be solid solution structures. Figure 2c, on the other hand, shows rodlike microcrystalline particles of $\mathrm{CeO}_{2}$.

The Point of Zero Charge (pHzpc) and Specific Surface Area. Table 1 shows the general surface information of the three materials. Cerium oxide exhibited the highest specific surface area $\left(122 \mathrm{~m}^{2} \mathrm{~g}^{-1}\right)$, followed by iron oxide $\left(98 \mathrm{~m}^{2} \mathrm{~g}^{-1}\right)$ and $\mathrm{Fe}-\mathrm{Ce} 08\left(90 \mathrm{~m}^{2} \mathrm{~g}^{-1}\right)$, indicating that doping of $\mathrm{Ce}^{4+}$ into the $\mathrm{Fe}(\mathrm{II}) / \mathrm{Fe}$ (III) system results in a slight decrease of surface area.

According to Stumm (31), the pHzpc of a composite oxide is approximately the weighted average of the values of its components. The pHzpc of Fe-Ce adsorbent (5.8), however, was even lower than that of the iron oxide (6.2), indicating that the $\mathrm{Fe}-\mathrm{Ce}$ system is not a physical mixture of iron oxide and cerium oxide. The surface of $\mathrm{Fe}-\mathrm{Ce}$ adsorbent was positively charged at $\mathrm{pH}<5.8$, which was favorable for nonspecific adsorption of As(V) through Coulombic attraction between anions and the adsorbent (32). A previous study indicated that high $\mathrm{As}(\mathrm{V})$ removal could be obtained even at $\mathrm{pH}>5.8$ (21), suggesting that specific adsorption might dominate in the adsorption of $\mathrm{As}(\mathrm{V})$ onto $\mathrm{Fe}-\mathrm{Ce}$ adsorbent.

As discussed above, all of the results of XRD, TEM, and pHzpc analysis demonstrated that introduction of proper amounts of $\mathrm{Ce}^{4+}$ ions into $\mathrm{Fe}(\mathrm{II}) / \mathrm{Fe}(\mathrm{III})$ systems results in the coexistence of $\mathrm{Ce}$ and Fe in the form of a solid solution, which is favorable for arsenic removal.

FTIR Spectra: Occurrence of Characteristic Surface $\mathrm{M}-\mathrm{OH}$ Groups. According to the surface complex model theory (31), metal hydroxyl groups on the surface of many metal oxides, which can be detected by IR spectroscopy, are the most abundant and reactive adsorption sites for anions. As an adsorbent based on hydrous metal oxides, $\mathrm{Fe}-\mathrm{Ce}$ bimetal oxide should contain some surface hydroxyl groups (M$\mathrm{OH}$; M represents surface metal ions of $\mathrm{Ce}$ or $\mathrm{Fe}$ ) in aqueous environments (3). 


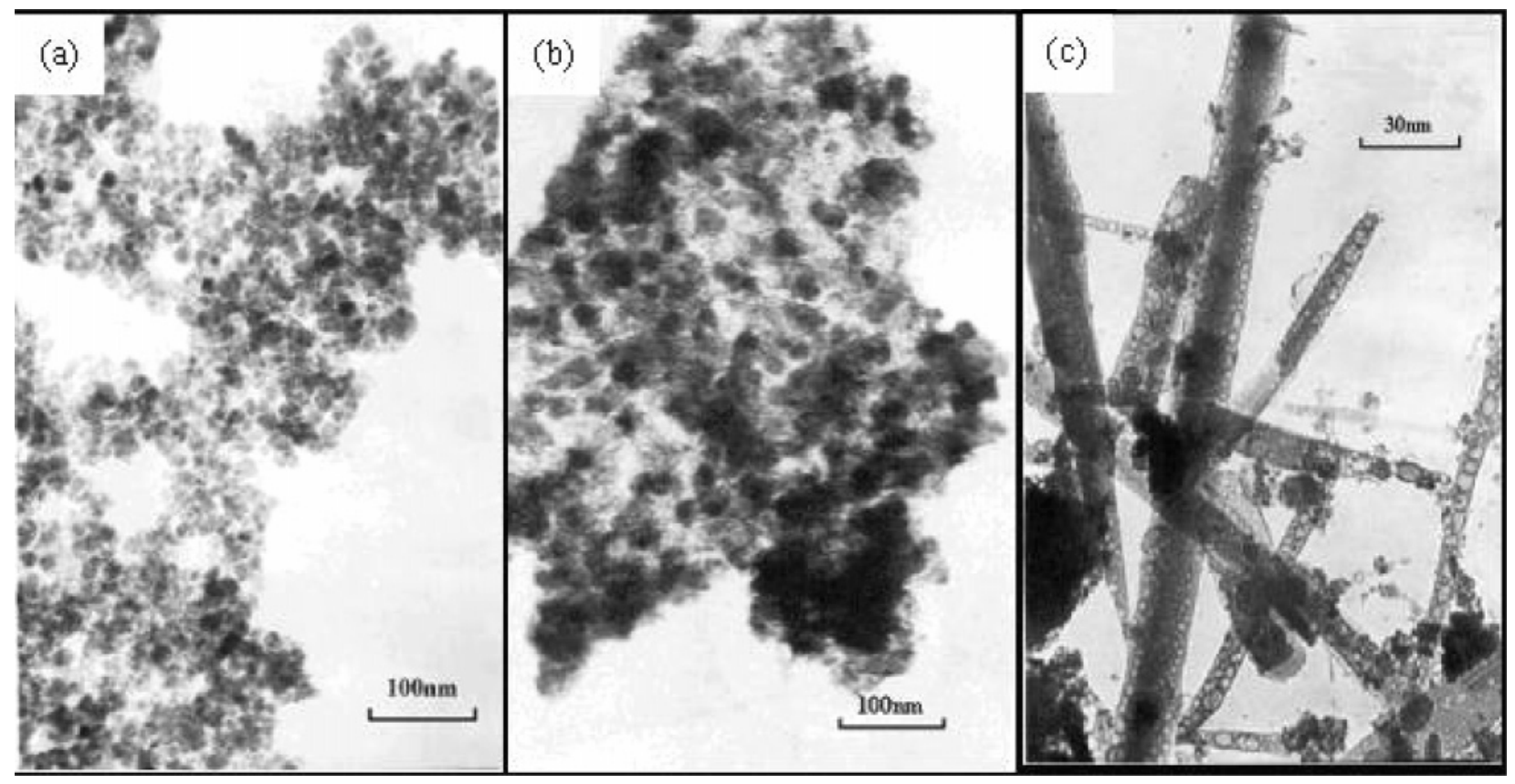

FIGURE 2. TEM images for (a) $\mathrm{Fe}_{3} \mathrm{O}_{4}(100000$ times magnification), (b) $\mathrm{Fe}-\mathrm{Ce} 08$ (100 000 times magnification), and (c) $\mathrm{CeO}$ (30 000 times magnification).

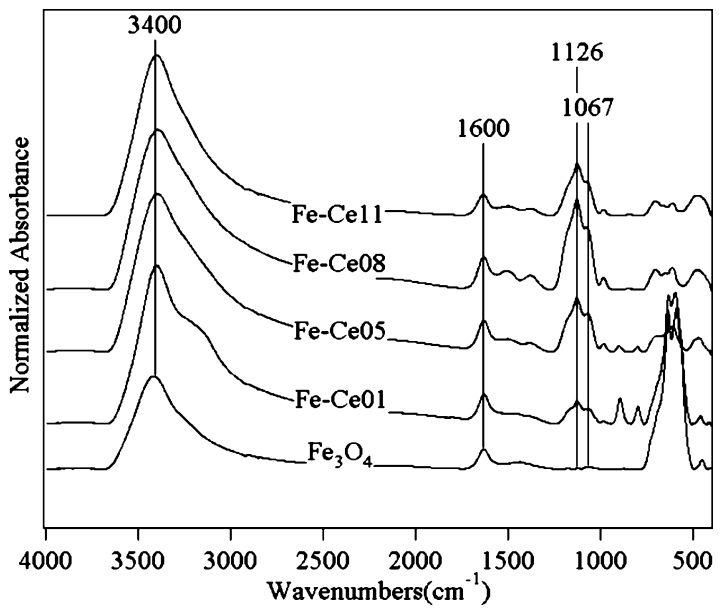

FIGURE 3. FTIR spectra for $\mathrm{Fe}_{3} \mathrm{O}_{4}$ and $\mathrm{Fe}-\mathrm{Ce}$ systems.

Figure 3 presents variations of FTIR spectra for the magnetite $\left(\mathrm{Fe}_{3} \mathrm{O}_{4}\right)$ and $\mathrm{Fe}-\mathrm{Ce}$ systems of different Ce doses. The FTIR spectra of magnetite has (1) HOH stretching (3550$3200 \mathrm{~cm}^{-1}$ ) and bending (near $1600 \mathrm{~cm}^{-1}$ ) vibration of water (33) and (2) broad bands at $580 \mathrm{~cm}^{-1}$ for $\mathrm{Fe}-\mathrm{O}$ with an additional, very weak band at $1067 \mathrm{~cm}^{-1}$ for $\mathrm{Fe}-\mathrm{OH}$ (34). Doping with Ce ions resulted in a decreased band intensity of $580 \mathrm{~cm}^{-1}$ and the formation of a new peak at $1126 \mathrm{~cm}^{-1}$. A drastic decrease of band intensity at $580 \mathrm{~cm}^{-1}$ for $\mathrm{Fe}-\mathrm{Ce} 05$ suggested that the $\mathrm{Fe}-\mathrm{O}$ bond of magnetite was destructed significantly under a system of $0.05 \mathrm{~mol} \mathrm{~L}^{-1} \mathrm{Ce}$ dose, which was supported by the above XRD result. The structure around $890 \sim 900 \mathrm{~cm}^{-1}$ is possibly the fingerprint of the presence of $\alpha$-FeOOH (goethite) in the sample (35). With further addition of Ce ions, however, the peak disappeared again.

According to Nakamoto (36), the two peaks (1126 and $1067 \mathrm{~cm}^{-1}$ ) of $\mathrm{Fe}-\mathrm{Ce}$ systems could be assigned to the bending vibration of hydroxyl groups of metal oxides (M$\mathrm{OH})$. The highest band intensity at $1126 \mathrm{~cm}^{-1}$ occurred at the Ce dose of $0.08 \mathrm{~mol} \mathrm{~L}^{-1}$, indicating that $0.08 \mathrm{~mol} \mathrm{Ce} \mathrm{L}^{-1}$ is the optimum condition for the generation of $\mathrm{M}-\mathrm{OH}$. Excessive doping of $\mathrm{Ce}^{4+}$ (e.g., $\mathrm{Fe}-\mathrm{Ce} 11$ ), however, leads to the decrease of band intensity at $1126 \mathrm{~cm}^{-1}$. The band intensity at $1067 \mathrm{~cm}^{-1}$, on the other hand, was almost constant for all of the systems. From the fact that the $\mathrm{Fe}-\mathrm{Ce} 08$ possesses the highest $\mathrm{As}(\mathrm{V})$ adsorption capacity, it is easy to speculate that the $\mathrm{M}-\mathrm{OH}$ groups detected at $1126 \mathrm{~cm}^{-1}$ in IR spectra are key surface groups in $\mathrm{As}(\mathrm{V})$ adsorption for $\mathrm{Fe}-\mathrm{Ce}$ systems. Considering the XRD results, it is clear that the transformation of the $\mathrm{Fe}-\mathrm{Ce}$ bimetal system from the magnetite phase to the solid solution phase led to the formation of abundant $\mathrm{M}-\mathrm{OH}$ groups, which might be the key arsenate adsorption sites.

FTIR Spectra Changes after As (V) Adsorption. The vibration models associated with the stretching and bending motions of $\mathrm{M}-\mathrm{OH}$ functional groups are sensitive to the presence of adsorbed anions, which can be detected by IR spectroscopy, a powerful means for investigating surface structures (13, 14).

FTIR spectra of $\mathrm{Fe}-\mathrm{Ce} 08$ adsorbent following adsorption in $\mathrm{As}(\mathrm{V})$ solutions containing $0.1-150 \mathrm{mg} \mathrm{L}^{-1}$ of $\mathrm{As}(\mathrm{V})$ at a $\mathrm{pH}$ of 5.0 for $24 \mathrm{~h}$ are shown in Figure $4 \mathrm{a}$. It is clear that the $\mathrm{M}-\mathrm{OH}$ bending bands $\left(1123 \mathrm{~cm}^{-1}\right)$ gradually disappeared, while a new band, corresponding to As-O stretching vibration $(14,36)$, appeared at $836 \mathrm{~cm}^{-1}$, and its intensity increased with the increase of $\mathrm{As}(\mathrm{V})$ concentration. The $\mathrm{M}-\mathrm{OH}$ bending bands $\left(1123 \mathrm{~cm}^{-1}\right)$ could almost not be observed when the adsorbate concentration reached $150 \mathrm{mg} \mathrm{L}^{-1}$. The effluent $\mathrm{pH}$ rose from the initial value of 5.0 to $\mathrm{pH}$ of $6.2-6.7$ following adsorption for $24 \mathrm{~h}$ (data not shown). From the changes of FTIR spectra and $\mathrm{pH}$, it was speculated that substitution of $\mathrm{M}-\mathrm{OH}$ groups by As $(\mathrm{V})$ ions plays a key role in the adsorption mechanisms, which is in accordance with the results obtained by Tokunaga et al. (7).

To verify the above assumption, the integral area of As $-\mathrm{O}$ band $(\mathrm{S}-\mathrm{As})$ at $836 \mathrm{~cm}^{-1}$ and $\mathrm{As}(\mathrm{V})$ adsorption capacity were plotted against the integral area of $\mathrm{M}-\mathrm{OH}$ bands $(\mathrm{S}-\mathrm{OH})$ at $1123 \mathrm{~cm}^{-1}$ over the whole As $(\mathrm{V})$ concentration range as shown in Figure 4b. It is clear that both the integral area of As-O band and $\mathrm{As}(\mathrm{V})$ adsorption capacity increased almost linearly $\left(R^{2}=0.97\right.$ and 0.99 , respectively) with the decrease of the integral area of the $\mathrm{M}-\mathrm{OH}$ band, which proves that the adsorption of $\mathrm{As}(\mathrm{V})$ by $\mathrm{Fe}-\mathrm{Ce} 08$ is realized primarily through the mechanism of quantitative ligand exchange. The bimetal adsorbent would lose its adsorption ability following the depletion of the $\mathrm{M}-\mathrm{OH}$ groups. 

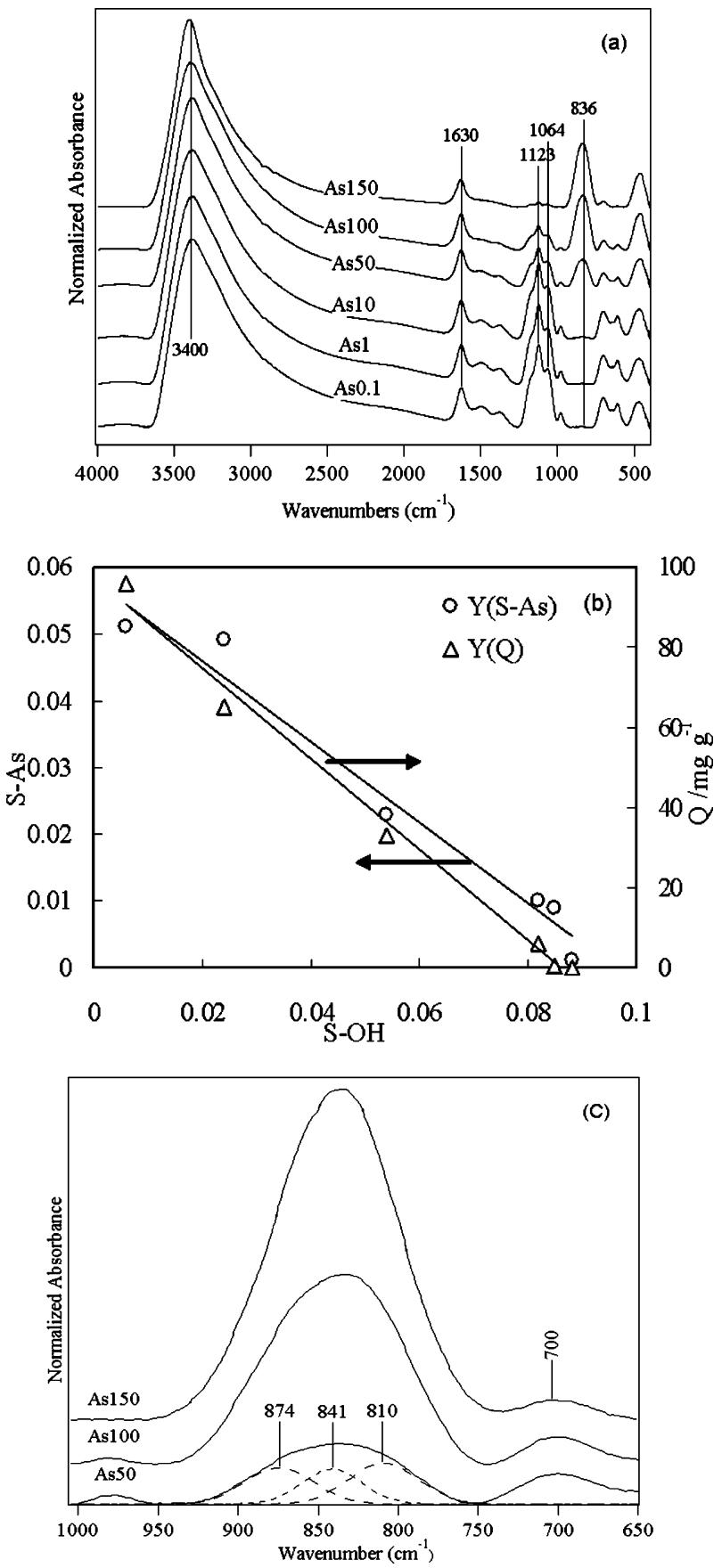

FIGURE 4. (a) The FTIR spectra of adsorbed species after As(V) adsorption on $\mathrm{Fe}-\mathrm{Ce} 08$ adsorbent. 0.1, 1.0, 10, 50, 100, and $150 \mathrm{mg}$ $\mathrm{L}^{-1}$ As(V) solution (As0.1, As1, As10, As50, As100, As150), $20^{\circ} \mathrm{C}, 24$ $h$, and $\mathrm{pH}$ 5.0. (b) Linear plots of integral area of $A s-0$ bands ( $S-$ $A s)$ and $A s(V)$ adsorption capacity $(Q)$ vs integral area of $\mathrm{M}-\mathrm{OH}$ band $(\mathrm{S}-\mathrm{OH}$ ) in $\mathrm{FTIR}$ spectra for $\mathrm{Fe}-\mathrm{Ce} 08$. Linear equation for $\mathrm{Y}(\mathrm{S}-$ As): $Y=-0.6069 X+0.0581, R^{2}=0.9697$; For $Y(Q): Y=-0.61132 .1 X$ $+97.414, R^{2}=0.9905$. (c) Fit transmission FTIR of arsenate adsorbed $\mathrm{Fe}-\mathrm{Ce} 08.50,100$, and $150 \mathrm{mg} \mathrm{L}^{-1} \mathrm{As}(\mathrm{V})$ solution (As50, As100, As150).

Adsorbed arsenate complexed species on $\mathrm{Fe}-\mathrm{Ce} 08$ were inspected by the splitting of $v_{3}(\mathrm{As}-\mathrm{O})$ vibration (Figure $4 \mathrm{c}$ ) on the basis of molecular symmetry and IR vibrational modes (15-18). Peak splitting is due to coordination on iron octahedral or protonation. Three overlapping bands were obtained from both the second derivative spectra and deconvoluted spectra on the basis of (1) the contribution to integrated band areas and (2) the minimum number of component bands for Gaussian profile fitting (data not shown) $(35,37)$. The positions of the three bands after deconvolution $\left(\cong 870,840,810 \mathrm{~cm}^{-1}\right)$ were similar to those of second derivative spectra $\left(\cong 870,840,820 \mathrm{~cm}^{-1}\right)$. Then, after Gaussian profile fitting, the hidden three $v_{3}$ bands were revealed at $836 \mathrm{~cm}^{-1}$ (Figure 4c). The broad spectra at initial As $(\mathrm{V})$ of $50 \mathrm{mg} \mathrm{L}^{-1}$ was an assemblage of three vibrations ( $\left.\cong 874 \mathrm{~cm}^{-1}, 841 \mathrm{~cm}^{-1}, 810 \mathrm{~cm}^{-1}\right)$. The first two bands were assigned to $v_{3}$ vibrations of $\mathrm{As}-\mathrm{O}-\mathrm{Fe}$ and $\mathrm{As}-\mathrm{O}-\mathrm{Fe} / \mathrm{H}-$ bonded, respectively $(15,38)$. The last band can be assigned to the $v_{3}$ vibration of $\mathrm{As}-\mathrm{O}-\mathrm{Fe} / \mathrm{Ce}$ under dry condition. Peak position and splitting of As-O band at $836 \mathrm{~cm}^{-1}$ were not changed with the increase of initial $\mathrm{As}(\mathrm{V})$ concentration (Figure 4c), which showed similar dominating surface complexed species under different $\mathrm{As}(\mathrm{V})$ concentrations. Arai and Sparks investigated phosphate adsorption mechanisms at the ferrihydrite-water interface and found that the spectra under different adsorption conditions were an assemblage of well-resolved triplet splitting of the $v_{3}(\mathrm{P}-\mathrm{O})$ vibration via Gaussian profile fitting analysis. They speculated from this result that bidentate binuclear $\left(\mathrm{C}_{2} v\right)$ and monodentate mononuclear phosphate complexes $\left(\mathrm{C}_{1}\right)$ predominantly form at the ferrihydrite $-\mathrm{H}_{2} \mathrm{O}$ interface at $\mathrm{pH} \geq 7.5$ and $\mathrm{pH}<7.5$, respectively (17). In this study, the triplet splitting of the $v_{3}$ vibration via Gaussian profile fitting analysis suggests the existence of $\mathrm{C}_{2 v}$ or lower symmetry $C_{1}$ point groups. While most of the $\mathrm{C}_{2 v}$ species were deprotonated (17), the low $\mathrm{pH}$ condition $(\mathrm{pH}=5)$ in this study favored the formation of the protonated species $\left(C_{1}\right)$. So, it is speculated that the surface complexed species of $\mathrm{As}(\mathrm{V})$ on $\mathrm{Fe}-\mathrm{Ce} 08$ under given experimental conditions might be the $C_{1}$ group, as shown in Figure $7 \mathrm{a}$ and $\mathrm{c}$.

XPS Spectroscopy. Surface structure information of Ce oxide, Fe oxide, and $\mathrm{Fe}-\mathrm{Ce} 08$ was analyzed by XPS before and after As $(V)$ binding adsorption. The XPS spectra of Ce3d, Fe2p, and O1s are shown in Figure 5a, b, and c, respectively. The binding energy of $\mathrm{Ce}(3 \mathrm{~d} 5 / 2)(885.8 \mathrm{eV})$ and the peak shape (a single broad peak) indicated that the dominating chemical state of $\mathrm{Ce}$ in $\mathrm{Fe}-\mathrm{Ce} 08$ was $\mathrm{Ce}(\mathrm{III})$, because the peak at $916.8 \mathrm{eV}(\mathrm{Ce}(\mathrm{IV}) 3 \mathrm{~d} 3 / 2)$ disappeared. The reduction of $\mathrm{Ce}$ (IV) was caused by $\mathrm{Fe}^{2+}$ during preparation of the adsorbent. This result demonstrates that the magnetite structure of the Fe oxide was destroyed through oxidation of $\mathrm{Fe}^{2+}$ by $\mathrm{Ce}^{4+}$. The dominating chemical state of $\mathrm{Ce}$ in $\mathrm{Ce}$ oxide, on the other hand, was Ce(IV). The Ce(3d) spectra of $\mathrm{Fe}-\mathrm{Ce} 08$ before and after $\mathrm{As}(\mathrm{V})$ binding adsorption showed little change, indicating that the chemical state of Ce atoms was not changed much after adsorption of $\mathrm{As}(\mathrm{V})$. This result suggests that Ce atoms might not directly participate in the adsorption of $\mathrm{As}(\mathrm{V})$. The $\mathrm{BE}$ value of $\mathrm{Fe}$ in $\mathrm{Fe}-\mathrm{Ce} 08(711 \mathrm{eV})$ and the peak shape of $\mathrm{Fe}(2 \mathrm{p} 3)$ in $\mathrm{Fe}-\mathrm{Ce} 08$ indicate that the Fe phase of $\mathrm{Fe}-\mathrm{Ce} 08$ can be assigned to $\mathrm{Fe}(\mathrm{III})-\mathrm{O}$ (Figure 5b). In comparison with the XPS Ce(3d5), a significant decrease of the $\mathrm{Fe}(2 \mathrm{p} 3)$ spectra intensity of $\mathrm{Fe}-\mathrm{Ce} 08$ was observed following As(V) adsorption, indicating the occurrence of strong interactions between $\mathrm{As}(\mathrm{V})$ and Fe atoms. So, the above results suggest that the Fe atoms played a key role in $\mathrm{As}(\mathrm{V})$ adsorption while the main role for Ce atoms was to form an amorphous structure through oxidation of $\mathrm{Fe}^{2+}$.

$\mathrm{O}(1 \mathrm{~s})$ narrow scans of the bimetal adsorbent before and after $\mathrm{As}(\mathrm{V})(\mathrm{Fe}-\mathrm{Ce} 08-\mathrm{As}(\mathrm{V}))$ binding adsorption are illustrated in Figure 5c together with the results for the other two materials. It is clear that the $\mathrm{O}(1 \mathrm{~s})$ spectra of the three oxides are quite different from each other, indicating that the three oxides have different chemical states of oxygen. The $\mathrm{O}(1 \mathrm{~s})$ spectra of $\mathrm{Fe}-\mathrm{Ce} 08$ and $\mathrm{Fe}-\mathrm{Ce} 0-\mathrm{As}(\mathrm{V})$ are also quite different, indicating that the oxygen constituents of $\mathrm{Fe}-\mathrm{Ce} 08$ changed significantly after $\mathrm{As}(\mathrm{V})$ adsorption. Because of the chemical adsorption between substrate and adducts, the peak of the $\mathrm{O}(1 \mathrm{~s})$ spectra of surface complexes has shifted to a less negative binding energy for $\mathrm{As}(\mathrm{V})$ adsorption from 531 to $530.4 \mathrm{eV}$ in Figure 5c. 

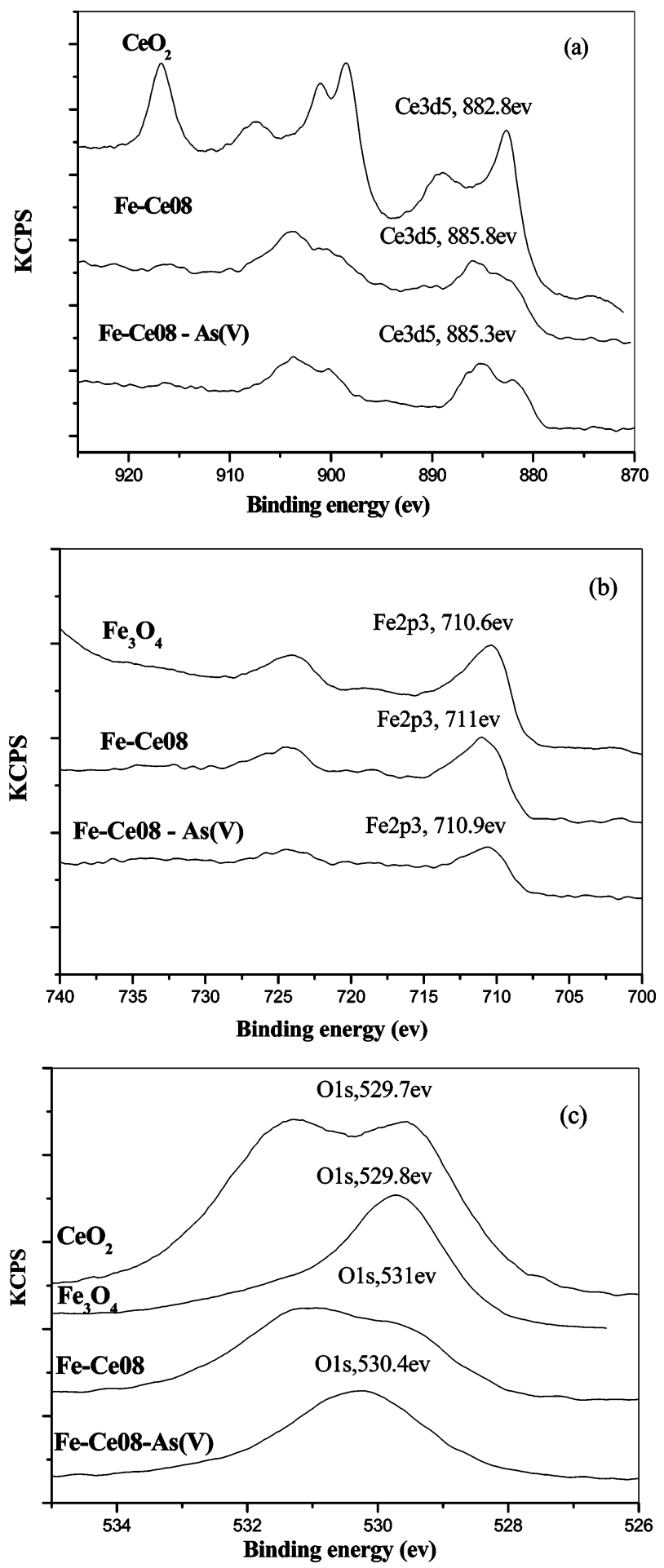

FIGURE 5. XPS spectra for (a) Ce3d5, (b) Fe2p3, and (c) 0 (1s) of different materials.

The $\mathrm{O}(1 \mathrm{~s})$ spectra of each oxide was composed of overlapped peaks of oxide oxygen $\left(\mathrm{O}^{2-}\right)$, hydroxyl $\left(\mathrm{OH}^{-}\right)$, and sorbed water $\left(\mathrm{H}_{2} \mathrm{O}\right)$. All of the spectra were fitted using a 50:50 Gaussian:Lorentzian peak shape (20), and satisfactory fitting results were obtained as shown in Figure $6 \mathrm{a}-\mathrm{d}$ and Table $2 . \mathrm{O}^{2-}$ was the most abundant $(72.08 \%$ and $42.09 \%)$ followed by $\mathrm{H}_{2} \mathrm{O}(15.30 \%$ and $38.32 \%)$ in $\mathrm{Fe}_{3} \mathrm{O}_{4}$ and $\mathrm{CeO}_{2}$ (Figure $6 \mathrm{a}$ and b). $\mathrm{OH}^{-}$, which was proven to be the key factor for $\mathrm{As}(\mathrm{V})$ adsorption by $\mathrm{Fe}-\mathrm{Ce} 08$, only occupied $12.62 \%$ and $19.59 \%$ of the total oxygen in $\mathrm{Fe}_{3} \mathrm{O}_{4}$ and $\mathrm{CeO}_{2}$, respectively. As shown in Figure $6 \mathrm{c}$ and Table 2, the doping of $\mathrm{Ce}^{4+}$ into the $\mathrm{Fe}^{2+} / \mathrm{Fe}^{3+}$ system resulted in a significant increase of the
$\mathrm{OH}^{-}(529.57 \mathrm{eV})$ species $(33.79 \%)$ in $\mathrm{Fe}-\mathrm{Ce} 08$, which is in accordance with the results obtained by FTIR. Changes of water content are observed. It is possible that some porous medium is formed. Another possibility is that the heat of adsorption of water would be higher on Ce oxides than on Fe oxides. It is interesting that the surfaces of $\mathrm{Fe}-\mathrm{Ce} 08$ became progressively hydroxylated following As $(\mathrm{V})$ adsorption $(56.06 \%)$ (Figure $6 \mathrm{~d}$ ) perhaps because of the formation of highly hydroxylated arsenate surface complexes, which will be discussed later.

The atomic ratio of $\mathrm{Ce}, \mathrm{Fe}, \mathrm{O}$, and As on the surface of $\mathrm{Fe}-\mathrm{Ce} 08$ before and after As binding adsorption are summarized in Table 3. As shown in Table 3, the surface of FeCe 08 contains $20.1 \%$ Fe and $6.1 \% \mathrm{Ce}$. After binding adsorption of $\mathrm{As}(\mathrm{V})$, the atomic ratio of $\mathrm{Fe}$ on the surface decreased drastically from $20.1 \%$ to $7.7 \%$ with the increase of the As atom ratio from 0 to $16 \%$, indicating that $\mathrm{Fe}$ atoms were overlaid by the adsorbed arsenate. The atomic ratio of Ce, on the other hand, remained almost constant (6.1-6.2\%) following $\mathrm{As}(\mathrm{V})$ adsorption. It is consistent with the previous finding of lacking of $\mathrm{Ce}(3 \mathrm{~d})$ spectra shift after $\mathrm{As}(\mathrm{V})$ adsorption (Figure 5a). The above results further proved that As(V) adsorption was realized through the replacement of the $\mathrm{OH}$ group of $\mathrm{Fe}-\mathrm{OH}$ with arsenate. It was therefore speculated that the main role of $\mathrm{Ce}$ is to break the magnetite structure of the $\mathrm{Fe}$ (II) / $\mathrm{Fe}$ (III) system through oxidation of $\mathrm{Fe}^{2+}$ and to activate the $\mathrm{Fe}$ atoms to acquire more $\mathrm{Fe}-\mathrm{OH}$. The atomic ratio of $\mathrm{O}$ on the other hand decreased from 73.8 to $69.8 \%$ after the adsorption of arsenate. The loss of $\mathrm{O}$ atoms because of the replacement of $\mathrm{M}-\mathrm{OH}$ was compensated for by the new $\mathrm{O}$ atoms from arsenate oxyanions, so the atomic ratio of $\mathrm{O}$ only changed slightly.

The above FTIR and XPS results showed that $\mathrm{Fe}-\mathrm{Ce} 08$ had many more $\mathrm{M}-\mathrm{OH}$ groups than $\mathrm{CeO}_{2}$ and $\mathrm{Fe}_{3} \mathrm{O}_{4}$ did, and the quantitative substitution of the $\mathrm{M}-\mathrm{OH}$ groups by $\mathrm{As}(\mathrm{V})$ ions plays a key role in $\mathrm{As}(\mathrm{V})$ adsorption. Since $\mathrm{Fe}-$ Ce08 had the lowest BET specific surface area among the three oxides (Table 1), the high concentration of $\mathrm{M}-\mathrm{OH}$ on the surface of $\mathrm{Fe}-\mathrm{Ce} 08$ was not due to the increase of specific surface area but was due to the high density of $\mathrm{M}-\mathrm{OH}$ existing on the surface of $\mathrm{Fe}-\mathrm{Ce} 08$.

There are three possible arsenate surface complexes resulting from the ligand exchange reaction: binuclear, bidentate, and monodentate complexes (Figure 7a-c) (12, 39,40 ). The monodentate and bidentate surface complexes have been used to explain the reaction step in anion adsorption by metal hydroxide on the basis of the quantitative relationship between hydroxyl ion release and As(V) adsorption (39-41). As shown in Figure 7, the stoichiometric ratio of surface hydroxyl between the intact adsorbent and the adsorbent saturated with $\mathrm{As}(\mathrm{V})$ ions was $1: 2$ for a monodentate surface complex, while it was $2: 1$ for a bidentate one. Figure $4 \mathrm{~b}$ indicates that $\mathrm{As}(\mathrm{V})$ adsorption was mainly realized through quantitative replacement of $\mathrm{M}-\mathrm{OH}$ with $\mathrm{As}(\mathrm{V})$ ions. Table 2 shows that the ratio of the $\mathrm{OH}$ to total oxygen atoms in $\mathrm{Fe}-\mathrm{Ce} 08$ increased from $33.79 \%$ to $56.06 \%$ after adsorption, giving a ratio of surface hydroxyl between $\mathrm{Fe}-\mathrm{Ce} 08$ and $\mathrm{Fe}-$ Ce08-As of 1:1.7, which was very close to diprotonated monodentate mononuclear complex species (Figure 7a, $\left.\mathrm{SOAsO}(\mathrm{OH})_{2}\right)$. It is consistent with the FTIR speculation above (Figure 4c). In another study using the same adsorbents, the dipronotated monodenate mononuclear species was confirmed on arsenate removal using the surface complexation modeling (FITEQL 4.0) (data not shown). So, it was speculated that the oxide surface of $\mathrm{Fe}-\mathrm{Ce} 08$ was covered mainly with monodentate surface complexes after adsorption. As shown in Figure 7a, a high portion of monodentate adsorption is more efficient for the removal of arsenate from water (3840). According to some EXAFS studies $(42,43)$, the dominant species of $\mathrm{As}(\mathrm{V})$ existing on iron oxide as well as on iron oxyhydroxide are reported as bidentate complexes. However, 

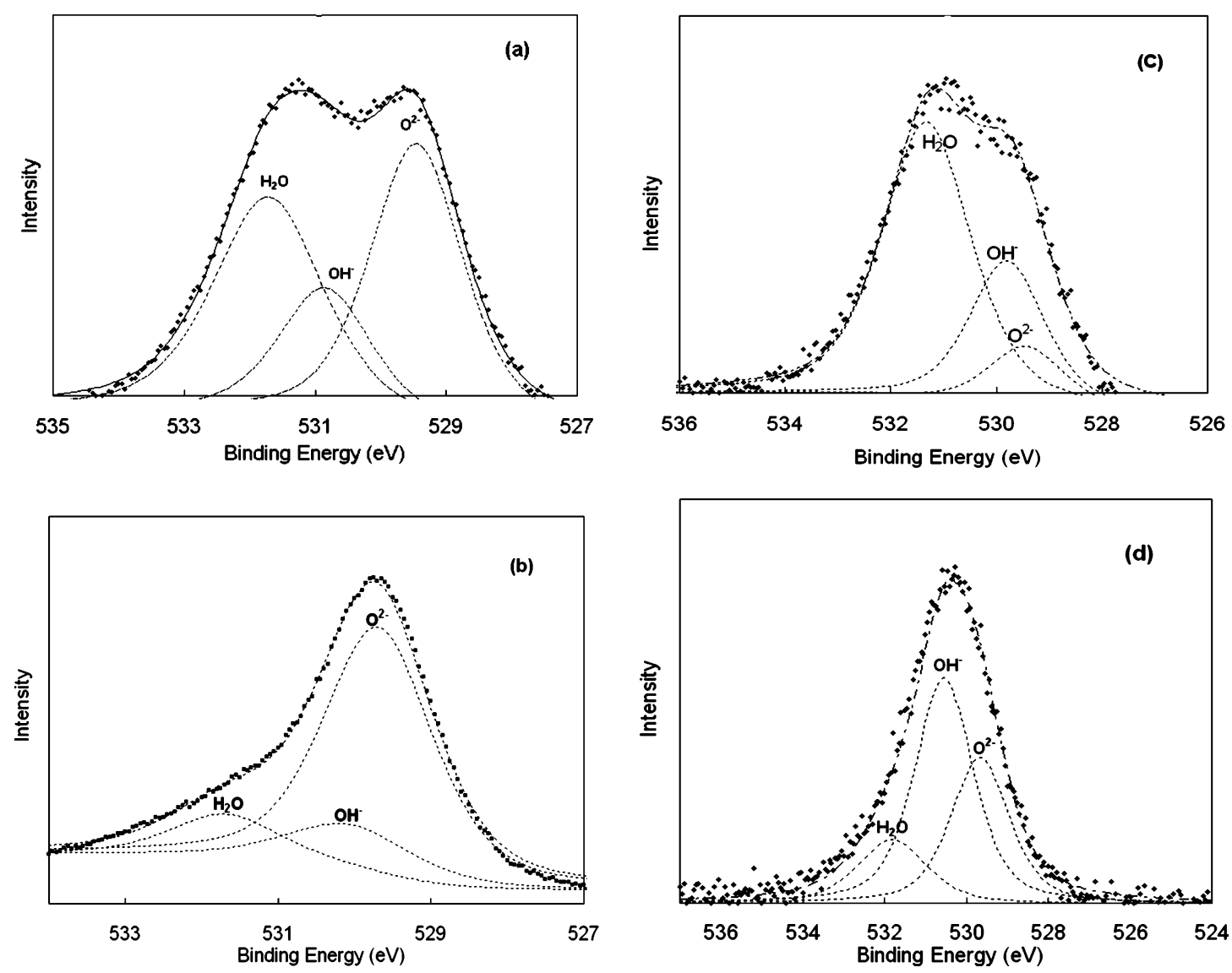

FIGURE 6. 0 (1s) spectra of (a) $\mathrm{CeO}_{2}$, (b) $\mathrm{Fe}_{3} \mathrm{O}_{4}$, (c) $\mathrm{Fe}-\mathrm{Ce} 08$, and (d) $\mathrm{Fe}-\mathrm{Ce} 08$ after As adsorption. The dotted curves represent photopeak contribution from $\mathrm{O}^{2-}$, from $\mathrm{OH}^{-}$, and from $\mathrm{H}_{2} \mathrm{O}$. The peak at the lowest binding energy is oxide $\left(\mathrm{O}^{2-}\right)$, the peak with intermediate binding energy is $\mathrm{OH}^{-}$, and the highest energy peak is that of $\mathrm{H}_{2} \mathrm{O}$. The fitted peak parameters are provided in Table 2.

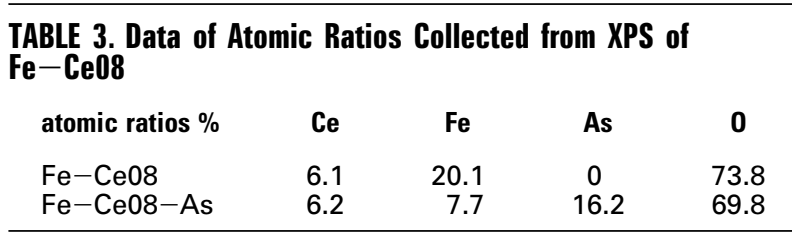

the $\mathrm{Fe}-\mathrm{Ce}$ system in the present study is different from iron oxides or oxyhydroxide. The existence of Ce atoms on the surface of the bimetal oxide is probably a reason for the dominant complex species of monodentate. On the other hand, the existence of monodentate complexes on iron oxides was also suggested by some EXAFS results $(12,44)$. In addition, elimination of the entrained water by drying prior to FTIR or XPS measurements might possibly cause the conversion from outer-sphere to inner-sphere complexes $(17,45)$. In our in-situ study on the same adsorbent, however, the formation of inner-sphere complexes were also confirmed by ionic strength dependence, electrophoretic mobility measurements, and so on (data not shown) (14). Further studies using ATR-IR, EXAFS, and other techniques, however, are required for confirming the above speculation.

In general, the bimetal oxide adsorbent ( $\mathrm{Fe}-\mathrm{Ce}$ system), which was developed by doping cerium ions into Fe(II)/ $\mathrm{Fe}(\mathrm{III})$ system, showed a significantly high arsenic adsorption capacity. The mechanism for $\mathrm{As}(\mathrm{V})$ adsorption to the $\mathrm{Fe}-\mathrm{Ce}$ adsorbent was investigated by collecting information about the adsorbent's structure using various methods such as XRD, TEM, FTIR, and XPS. The formation of a solid solution structure, which was characterized by a high concentration of $\mathrm{M}-\mathrm{OH}$ groups, was proposed as the main reason for the high adsorption capacity of $\mathrm{Fe}-\mathrm{Ce} 08$. As $(\mathrm{V})$ adsorption was realized through the replacement of the $\mathrm{OH}$ group of $\mathrm{Fe}-$

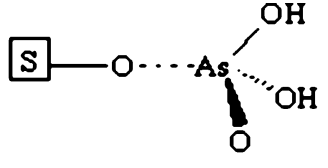

(a)<smiles></smiles>

(b)<smiles></smiles>

(c)

FIGURE 7. Possible configurations of the arsenate surface complexes. (a) Monodentate complex; (b) bidentate mononuclear complex, and (c) bidentate binuclear complex $(12,39,40)$.

$\mathrm{OH}$ with arsenate. The main role of $\mathrm{Ce}$ is to break the magnetite structure of the $\mathrm{Fe}(\mathrm{II}) / \mathrm{Fe}$ (III) system through oxidation of $\mathrm{Fe}^{2+}$ and to activate the $\mathrm{Fe}$ atoms to acquire more $\mathrm{Fe}-\mathrm{OH}$. $\mathrm{As}(\mathrm{V})$ adsorption was realized through the formation of the possible diprotonated monodentate mononuclear complexes species by quantitatively replacing the $\mathrm{M}-\mathrm{OH}$ with $\mathrm{As}(\mathrm{V})$ ions. The results obtained as well as the approaches used in this study will be helpful for gaining a better understanding of anionic adsorption mechanisms and for selecting and developing high-efficiency adsorbents.

Granular $\mathrm{Ce}-\mathrm{Fe} 08$ adsorbent (diameter, $1 \mathrm{~mm}$ ) has been successfully prepared using the vibration dropping method, and they were applied for the removal of arsenic from groundwater containing As of $60-100 \mu \mathrm{g} \mathrm{L}^{-1}$ in a suburb 
area of Beijing, China. Results of four months column experiments on the spot show that $\mathrm{Fe}-\mathrm{Ce} 08$ adsorbent could remove As from groundwater with high efficiency and meet the rigorous criteria of WHO $\left(10 \mu \mathrm{g} \mathrm{L}^{-1}\right)$. This part of the result will be reported in a future paper.

\section{Acknowledgments}

This work was supported by the National Natural Science Foundation of China (Contract No. 20207013). The authors are thankful to Dr. K. Tanaka, honorary professor of Tokyo University, Japan, for his kind help. We also thank the reviewers for their helpful comments and valuable suggestions.

\section{Literature Cited}

(1) Technologies and Costs for Removal of Arsenic from Drinking Water, EPA-815-R-00-028; U.S. Environmental Protection Agency, Office of water: Washington, DC, 2000.

(2) Gencü, F. H.; Tjell, J. C.; McConchie, D. Adsorption of arsenic from water using activated neutralized red mud. Environ. Sci. Technol. 2004, 38, 2428-2434.

(3) Cornell, R. M.; Schwertmann, U. The Iron Oxide, 1st ed.; VCH Publishers: New York, 1996.

(4) Hsia, T. H.; Lo, S. L.; Lin, C. F.; Lee, D. Y. Characterization of arsenate adsorption on hydrous iron oxide using chemical and physical methods. Colloids Surf., A 1994, 85, 1-7.

(5) Munoz, J. A.; Gonzalo, A.; Valiente, M. Arsenic adsorption by Fe(III)-loaded open-celled cellulose sponge. Thermodynamic and selectivity aspects. Environ. Sci. Technol. 2002, 36, 34053411.

(6) Hideaki, I.; Junji, N.; Yuzuru, I.; Tokuzo, K. Anion adsorption behavior of rare earth oxide hydrates. Chem. Soc. Jpn. 1987, 5, 807-813 (in Japanese, with English abstract).

(7) Tokunaga, S.; Hardon, M. J.; Wasay, S. A. Removal of fluoride ions from aqueous solution by multivalent metal compounds. Int. J. Environ. Stud. 1995, 48, 17-28.

(8) Arsenic in Groundwater from Major Aquifers: Sources, Effects and Potential Mitigation; DFID summary report; British Geological Survey: London, 2000.

(9) Hingston, F. J.; Atkinson, R. J.; Posner, A. M.; Quirk, J. P. Specific adsorption of anions. Nature 1967, 215, 1459-1461.

(10) Becker, U.; Hochella, M. F., Jr.; David, J. V. The adsorption of gold togalena surfaces: Calculation of adsorption/reduction energies, reaction mechanism, XPS spectra, and STM images. Geochim. Cosmochim. Acta 1997, 61, 3565-3585.

(11) Brown, G. E., Jr. Spectroscopic studies of chemisorption reaction mechanisms at oxide-water interface. In Mineral-Water Interface Geochemistry; Hochella, Jr., White, A. F., Eds.; Mineralogical Society of America: Washington, DC, 1990; Vol. 23, pp 309364.

(12) Fendorf, S.; Eick, M. J.; Grossl, P.; Sparks, D. L. Arsenate and chromate retention mechanisms on goethite. 1. Surface structure. Environ. Sci. Technol. 1997, 31, 315-319.

(13) Sun, X. H.; Doner, H. E. An investigation of arsenate and arsenite bonding structures on goethite by FTIR. Soil Sci. 1996, 161, 865-872

(14) Goldberg, S.; Johnston, C. T. Mechanisms of arsenic adsorption on amorphous oxides evaluated using macroscopic measurements, vibrational spectroscopy, and surface complexation modeling. J. Colloid Interface Sci. 2001, 234, 204-216.

(15) Satish, C. B. M.; Traina S. J.; Waychunas G. A.; Logan T. J. Experimental and theoretical vibrational spectroscopic evaluation of arsenate coordination in aqueous solutions, solids, and at mineral-water interfaces. Geochim. Cosmochim. Acta 1998, $62,3285-3300$

(16) Peak, D.; Luther G. W.; Sparks D. L. ATR-FTIR spectroscopic studies of boric acid adsorption on hydrous ferric oxide. Geochim. Cosmochim. Acta 2003, 67, 2551-2560.

(17) Arai, Y.; Sparks, D. L. ATR-FTIR spectroscopic investigation on phosphate adsorption mechanisms at the ferrihydrite-water interface. J. Colloid Interface Sci. 2001, 241, 317-326.

(18) Peak, D.; Ford, R. G.; Sparks, D. L.; An in situ ATR-FTIR investigation of sulfate bonding mechanisms on goethite. $J$. Colloid Interface Sci. 1999, 218, 289-299.

(19) Ding, M.; Dejong, B. H. W. S.; Roosendaal S. J.; Vredenberg, A. XPS studies on the electronic structure of bonding between solid and solutes: Adsorption of arsenate, chromate, phosphate, $\mathrm{Pb}^{2+}$, and $\mathrm{Zn}^{2+}$ ions on amorphous black ferric oxyhydroxide. Geochim. Cosmochim. Acta 2000, 64, 1209-1219.

(20) Nesbitt, H. W.; Canning, G. W.; Bancroft, G. M. XPS study of reductive dissolution of $7 \AA$-birnessite by $\mathrm{H}_{3} \mathrm{AsO}_{3}$, with con- straints on reaction mechanism. Geochim. Cosmochim. Acta 1998, 62, 2097-2110.

(21) Zhang, Y.; Yang, M.; Huang, X. Arsenic (V) removal with a Ce (IV)-doped iron oxide adsorbent. Chemosphere 2003, 51, 945952.

(22) Zhang, Y.; Yang, M.; Gao, Y. X.; Wang, F.; Huang, X. Preparation and adsorption mechanism of rare earth-doped adsorbent for arsenic(V) removal from groundwater. Sci. China, Ser. B 2003, $46,252-258$.

(23) Park, S. W.; Huang, C. P. The surface acidity of hydrous CdS (s). J. Colloid Interface Sci. 1986, 117, 431-441.

(24) Lafferty, B. J.; Loeppert, R. H. Methyl arsenic adsorption and desorption behavior on iron oxides. Environ. Sci. Technol. 2005 $39,2120-2127$.

(25) Zeng L. A method for preparing silica-containing iron(III) oxide adsorbents for arsenic removal. Water Res. 2003, 37, 43514358.

(26) Munoz, J. A.; Gonzalo, A.; Valiente, M. Arsenic Adsorption by Fe(III)-loaded open-celled cellulose sponge. Thermodynamic and selectivity aspects. Environ. Sci. Technol. 2002, 36, 34053411.

(27) Vérronique L.; Omar B.; Véronique D.; Bernard S.; Jean C. B. Arsenic adsorption onto pillared clays. J. Colloid Interface Sci. 2002, 255, 52-58.

(28) Fukushi, K.; Sato, T.; Yanase, N. Solid-solution reactions in As(V) sorption by schwertmannite. Environ. Sci. Technol. 2003, 37, 3581-3586.

(29) Hlavay J.; Polyák, K. Determination of surface properties of iron hydroxide-coated alumina adsorbent prepared for removal of arsenic from drinking water. J. Colloid Interface Sci. 2005, 284, $71-77$.

(30) Kim, Y.; Kim, C.; Choi, I.; Rengaraj, S.; Yi, J. Alumina Prepared via a templating method. Environ. Sci. Technol. 2004, 38, 924931.

(31) Stumm, T. Chemistry of the Solid-Water Interface; John Wiley: New York, 1992.

(32) Wasay, S. A.; Hardon, M. J.; Tokunaga, S. Adsorption of fluoride, phosphate, and arsenate ions on lanthanum-impregnated silica gel. Water Environ. Res. 1996, 68, 295-300.

(33) Russell, J. D. Infrared spectroscopy of ferrihydrite: evidence for the presence of structural hydroxyl groups. Clay Miner. 1979, $14,109-114$.

(34) Keiser, J. T.; Brown, C. W.; Heidersbach, R. H. The electrochemical reduction of rust filsm on weathering surface. $J$. Electrochem. Soc. 1982, 129, 2686-2689.

(35) Ruan, H. D.; Frost, R. L.; Kloprogge, J. T.; Duong, L. Infrared spectroscopy of goethite dehydroxylation: III. FT-IR microscopy of in situ study of the thermal transformation of goethite to hematite. Spectrochim. Acta, Part A 2002, 58, 967-981.

(36) Nakamoto, K. Infrared and Raman Spectra of Inorganic and Coordination Compounds, 3rd ed.; John Wiley: New York, 1978.

(37) Martens, W.; Frost, R. L. An infrared spectroscopic study of the basic copper phosphate minerals: Cornetite, libethenite, and pseudomalachite. Am. Mineral. 2003, 88, 37-46.

(38) Haarison, J. B.; Berkheiser, V. Anion interactions with freshly prepared hydrous iron oxides. Clay Miner. 1982, 30, 97-102.

(39) Manning, B. A.; Goldberg, S. Adsorption and stability of arsenic(III) at the clay mineral-water interface. Environ. Sci. Technol. 1997, 31, 2005-2011.

(40) Shin, E. W.; Han, J. S.; Jang, M.; Min, S. H.; Park, J. K.; Rowell, R. M. Phosphate adsorption on aluminum-impregnated mesoporous silicates: surface structure and behavior of adsorbents. Environ. Sci. Technol. 2004, 38, 912-917.

(41) The Nature and Properties of Soils, 12th ed.; Brady, N. C., Weil, R. R., Eds.; Prentice Hall: NJ, 1999.

(42) Sherman, D. M.; Randall, S. R. Surface complexation of arsenic(V) to iron(III) (hydr)oxides: Structural mechanism from ab initio molecular geometries and EXAFS spectroscopy. Geochim. Cosmochim. Acta 2003, 67 (22), 4223-4230.

(43) O'Reilly, S. E.; Strawn, D. G.; Sparks, D. L. Residence time effects on arsenate adsorption/desorption mechanisms on goethite. Soil Sci. Soc. Am. J. 2001, 65, 67-77.

(44) Waychunas, G. A.; Rea, B. A.; Fuller, C. C.; Davis, J. A. Surface chemistry of ferrihydrite: part 1. EXAFS studies of the geometry of coprecipitated and adsorbed arsenate. Geochim. Cosmochim. Acta 1993, 57, 2251-2269.

(45) Mineral-Water Interfacial Reactions: Kinetics and Mechanisms; Sparks, D. L., Grundl, T. J., Eds.; ACS Symposium Series; American Chemical Socity: Washington, DC, 1998.

Received for review April 21, 2005. Revised manuscript received June 23, 2005. Accepted July 7, 2005.

ES050775D 